\title{
Influence of Corporate Governance on Firm Value Through Intellectual Capital and Corporate Social Responsibility
}

\author{
Zainab Masitha (Corresponding Author) \\ Student in Accounting Master, Faculty of Economic and Business \\ Sebelas Maret University, Surakarta, Indonesia \\ E-mail: zmasitha3@gmail.com
}

Djuminah

Doctor of Accounting Department Faculty of Economic and Business

Sebelas Maret University, Surakarta, Indonesia

E-mail: djuminah80@gmail.com

Received: Jul. 23, 2019 Accepted: Oct. 24, 2019 Online published: Nov. 15, 2019

doi:10.5296/jpag.v9i4.15135ＵRL: https://doi.org/10.5296/jpag.v9i4.15135

\begin{abstract}
This study aims to find out empirical evidence about the influence of corporate governance on firm value through intellectual capital and corporate social responsibility. The sample used in this study amounted to 123 manufacturing companies listed on the Indonesia Stock Exchange continuously during the period 2015-2017 using purposive sampling technique. This study uses quantitative methods with secondary data obtained from annual reports that have been published by the Indonesia Stock Exchange during the period 2015-2017, which can be accessed through www.idx.co.id. Data analysis in this study uses Structural Equation Modeling based on Partial Least Square (SEM-PLS) with SmartPLS 3.0 software.

The results showed that the board of commissioners had a significant negative effect on intellectual capital and had a significant positive effect on corporate social responsibility. Board of Commissioners has a significant positive effect on intellectual capital and has a significant negative effect on corporate social responsibility. The board of commissioners, audit committees, intellectual capital and corporate social responsibility have a positive and significant effect on firm value. Intellectual capital is not able to mediate the relationship
\end{abstract}


between the board of commissioners and firm value, as well as the relationship of the audit committee to firm value. CSR is not able to mediate the relationship between the board of commissioners and firm value and the relationship between the audit committee and firm value.

Keywords: board of commissioners, audit committee, intellectual capital, corporate social responsibility, firm value

\section{Introduction}

The level of success of a company can be seen from the company, where investors will make the indicator value of the company for the financial management of the company. The company's value is the perception of investors about the condition of a company, which often refers to the share price. The demonstrated high stock price appreciation of the companies are too high. It is known that one of the objectives of the establishment of a corporation is to maximize the wealth of shareholders by increasing the value of the company, so that the shareholders would invest capital to companies (Bringham \& Houston, 2011).

Information is a fundamental requirement for investors and prospective investors in making decisions. The information disclosed related companies determine the value of companies such ascorporate governance, Intellectual capital, and corporate social responsibility. The application of good corporate governance can affect the value of the company by ensuring investors that the funds they invest for financing activities, investment, and growth of the company are used appropriately and efficiently and ensure management acts in the best interest of the company (Tumirin, 2007). Corporate governance mechanism involves many things, for example, the number of commissioners, the independence of the commissioners, the size of the board of directors, and the existence of an audit committee. Utilization of intellectual capital effectively and efficiently will affect the achievement of increased competitive advantage and will be reflected in the company's value is high (Faza \& Hidayah, 2014).

(Sukmono \& Yadiati, 2016) found that the commissioners have a significant positive effect on the value of the company. According (Windasari \& Riharjo, 2017) argues that the board of commissioners negatively affect the development of the company's value. The existence of the commissioners not only be regarded as complementary, because the commissioner attached themselves legally liable. Therefore, the role of the commissioner is very important. Through the role of commissioners in performing supervisory functions that may affect the management in preparing the financial statements in order to obtain a quality of a company's value.

Results of research from Bambang and (Chotimah \& Amanah, 2013) revealed that the commissioners did not significantly affect the value of the company. Companies in the implementation of corporate strategy, overseeing management in managing the company, as well as effective accountability requires less effective in monitoring the implementation ofcorporate governancewhich can increase the value of the company. The research was supported by (Ward, 2013) that the size of the board of directors is not a key determinant of 
the effectiveness of the supervision of the management company.

According to research conducted by (Rustriani, 2010) and supported by research (Daughter, 2010) that the audit committee can help the company monitor the application corporate governance good, which will be able to increase the value of the company. The responsibility of the audit committee in corporate governance is to ensure that the company has been run according to the rules.

Research conducted by (Ward, 2013) gives the results of that audit committees had no significant effect on firm value. It is clear that there is a possibility of the existence of an audit committee is not a guarantee that performance will be good, so the market perceive the existence of an audit committee is not a factor to be considered in appreciating the value of the company. Research by (Fidhayatin \& Goddess, 2012), stating that the absence of the influence of audit committee because the company's value is not optimal in the performance of the audit committee in monitoring and implementing the internal control of the company.

(Sunarsih \& Mendra, 2012) argues that when a company is able to manage the assets and equity, to manage its human resources and the ability to improve the competence and competitive advantage, the financial performance will improve. With increased corporate performance conditions, the profit will increase and will increase the company's value in the eyes of investors, intellectual capitalan important factor in raising the company's value. The results of this study reinforced previous research, (Suwarjuwono \& Kadir, 2003), (Ulum, 2008), (Pramelasari, 2010) which states that the intellectual capital can increase the value of the company, because intellectual capital and knowledge base in the form of an intangible asset that can be used as a value added for the company.

According to research from (Faza \& Hidayah, 2014) and supported by research conducted by (Suhendah, 2012), stating that there was no significant effect of intellectual capital on firm value. this means that the size of the intellectual capital increasingly affect the value of the company. Indonesia as a developing country still does not give more attention to the intellectual capital because intellectual capital is still a new concept for countries, especially developing countries.

(Zuhroh \& Sukmawati, 2003) and supported by research (Murwaningsari, 2009) states that the higher the level of disclosure corporate social responsibilitywill result in an increase in the value of the company. In theory, the disclosure of CSR should be a consideration for investors, because it contains social information the company has done. Companies that have the performance and social environments that will either responded positively by investors through an increase in the company's stock price. The higher the stock price, the more steeper corporate value.

(Ward, 2013) which is supported by the research of (Rara \& Hadiprajitno Basuki, 2012) in his research stating that the investor does not respond to the disclosure corporate social responsibilitythat has been done by the company. There are indications if the investors do not need to look at CSR disclosure by the company, because there is a guarantee that indicated on the Limited Liability Company Act No. 40 of 2007, that the company would implement CSR 
and express it, because if it is not implemented then the company will be sanctioned in accordance with the provisions. So it makes corporate social responsibility does not give effect to the value of the company.

Based on the results of previous studies that there are differences in the results of this interesting topic to be researched back. This study draws on research that has been done by (Sukmono \& Yadiati, 2016). Previous research using a sample of banking companies listed in Indonesia Stock Exchange during the years 2012-2014. Differences of this research with the research done by adding a variable sebelunyaintellectual capital and corporate social responsibility. This study uses a different sample of the research (Sukmono \& Yadiati, 2016) which used a sample of manufacturing companies listed in Indonesia Stock Exchange during the period 2015-2017. That is because the manufacturing company is a type of business that is growing rapidly and has a very large scope (most listed on the Stock Exchange), so it is considered to represent the overall issuers listed on the Indonesia Stock Exchange.

Every establishment of a company must have a clear purpose. Good company, a company that is able to achieve its objectives. The aim of such companies get the maximum profit, the welfare of the owners of the company, and maximize the value of the company which is proxied by stock prices. High enterprise value serves as a medium of competitive strategy to attract investors in order to invest in a company. The company's value in this study are influenced by the BOC (Sukmono \& Yadiati, 2016); (Windasari \& Riharjo, 2017); (Chotimah \& Amanah, 2013); (Ward, 2013), the Audit Committee (Rustriani, 2010); (Daughter, 2010), Intellectual capital (Sunarsih \& Mendra, 2012), (Suwarjuwono \& Kadir, 2003); (Ulum, 2008); (Pramelasari, 2010); (Faza \& Hidayah, 2014); (Suhendah, 2012), and Corporate social responsiblity (Zuhroh \& Sukmawati, 2003); (Murwaningsari, 2009); (Ward, 2013); (Rara \& Hadiprajitno Basuki, 2012).

In previous studies there are differences of opinion on hubunan between the commissioners and the audit committee of the value of the company so that more research is needed to prove those opinions. In addition this study examinesintellectual capital and corporate social responsibility as an intervening variable that will affect the independent variable, namely the board of directors and audit committee on the dependent variable, the value of the company.

Based on the background of the above problems, the formulation of the problem in this research are: 1. How does the size of the Board of Commissioners on Intellectual Capital?How to influence the size of the Board of Commissioners on Corporate Social Responsibility? How to measure the influence of the Board of Commissioners of the Company Values? How to influence the Audit Committee of the Intellectual Capital? How to influence the Audit Committee of the Corporate Social Responsibility? How to influence the Audit Committee of the Company's Value? How does the influence of Intellectual Capital on Firm Value? How does the influence of Corporate Social Responsibility Corporate Values?

\subsection{Stakeholder Theory}

Stakeholder theory emphasizes the accountability of the organization far beyond simple financial or economics. This theory states that the organization will choose voluntarily 
disclose information on environmental performance, social and intellectual organizations, over and above the obligatory request, in order to meet the expectations or recognized by stakeholders (Deegan, 2004). Management is responsible for the stakeholders in the decisions that will be taken for the benefit of the company. Thus, the manager of the company's reported financial statements requires consideration of stakeholder (Dewi, Inggi Rovita, 2014). The stakeholders that include company owners, employees, customers, suppliers, government and the community, and others.

This theory is generally associated with tips companies in managing their stakeholders (Ulum, 2008). The purpose of stakeholder theoryis in order to assist the company's management in terms of minimizing the losses that will be experienced by the stakeholders and help to increase the value obtained from the various activities that have been carried out. If the manager can memanfatakan resources and potential that exists in terms of optimizing the management of the company, such as employees (human capital), capital (physical capital), as well as the structural capital, so that the manager is said to have been able to create value added for companies that can improve the performance of the company's stakeholder interests.

In the case of acquiring a value, stakeholder management seeks to control the various ways one of them with a reward. So as to improve the welfare of the company are realized by more and more in height returns obtained by the management. So this theory is able to explain that the manager should be able to manage the company optimally to obtainvalue added which will drive the company's performance in terms of improving the competitive advantage of companies in which it will ultimately generate value for the company.

\subsection{Knowledge Based View (KBV)}

View Knowledge Based Viewis a combination of the two theories, namely the Resource-Based View (RBV) and the Market-Based View (MBV). Knowledge-Based View is a view showing that knowledge in its various forms is the importance of resources (Sangkala, 2006). This view considers knowledge is used as a resource appears very startegik for companies based on the fact that knowledge can be qualified as a strategic resource that can be used to develop the competitiveness of the company. As for the condition, among others, 1) worth, 2) a rare, 3) difficult to imitate competitors, 4) can not be replaced (Sangkala, 2006). In the current era of competition, companies often compete by developing new knowledge faster than the other competitors.

Knowledge-basedcharacterized by scarcity and difficult to achieve a competitive advantage. The capacity and effectiveness of the enterprise to generate, share and deliver knowledge and information on how to determine the value of the resulting company can serve as the basis of sustainable competitive advantage in the long term (Bontis, 2002). By recognizing knowledge as a strategic asset resulting knowledge is necessary to control, management, realization, and estimation. An understanding of this theory is used to understand the existence of Intellectual Capital. 


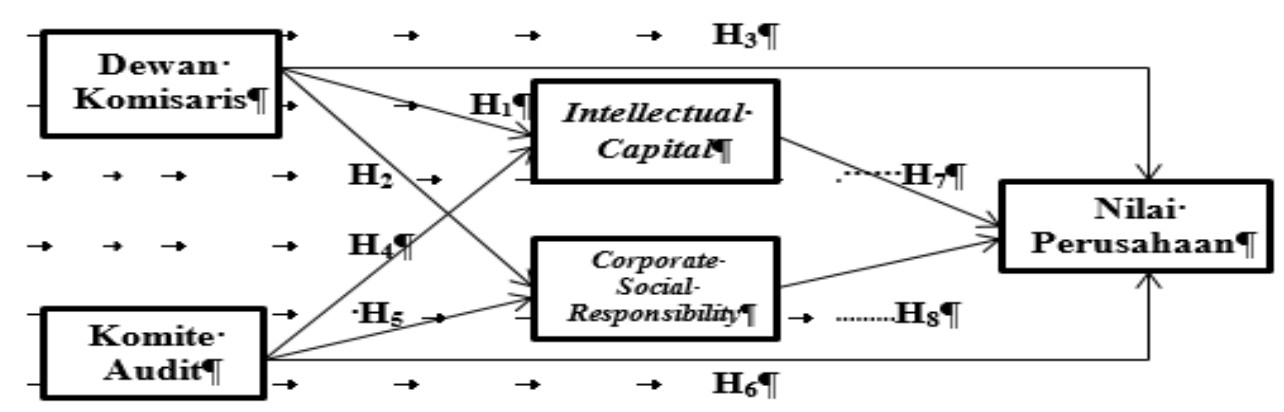

Figure 1. Theoretical Framework

The main problem of this study is to determine how much influence the structure of corporate governance in enhancing corporate value through intellectual capital and corporate social responsibility. Corporate governance is meant is the board of commissioners and the audit committee. The value of the company isinvestor perception of the condition of a company. There are 5 hypothesis in this study, namely: 1) commissioners positive effect on intellectual capital; 2) commissioners positive effect on CSR; 3) The board of directors has a positive effect on firm value; 4) the audit committee has a positive effect on intellectual capital; 5) the audit committee has positive influence on CSR; 6) the audit committee has a positive effect on firm value; 7) intellectual capital has a positive effect on firm value; and 8) CSR has a positive effect on firm value.

\section{Research Method}

This study examined several factors that can affect the value of companies such as board of directors, audit committee, intellectual capital, and corporate social responsibility on the dependent variable that has been determined, that the value of companies in the manufacturing companies have gone public on the Indonesian Stock Exchange for the period of 2015- 2017. This study uses a quantitative paradigm. According (Sekaran, 2017), testing the hypothesis usually describe the nature of the particular relationship or establish a difference in those groups, or the independence of two or more factors in a situation. Type of this investigation is causal research. Causal research is a study where researchers will describe the cause of one or several issues.

The population in this study are all manufacturing companies listed in Indonesia Stock Exchange from 2015-2017. Purposive sampling was used in the sampling in this study. This is because purposive sampling is a sampling technique of non-random sampling where the researcher determine the sampling by defining the characteristics or specific criteria in accordance with the purpose of research that is expected to answer the research problems. Yan criteria used in the selection of the sample as follows: 1.Perusahaan listed on the Stock Exchange of years in succession from 2015 to 2017; 2.Perusahaan manufacturing to submit financial statements as of December 31 in the currency Rupiah; 3. Manufacturing companies that publish and publicize the annual report and financial statements consistently during the years 2015 - 2017 have been published; 4. The manufacturing company that did not experience a loss during the years 2015-2017. 


\section{Macrothink}

Data used in this research is secondary data. Secondary data is the source of the data obtained by researchers indirectly through an intermediary medium (obtained and recorded by the other party) in the form of evidence, records or historical reports that have been compiled in the archives (data dokumentar published and unpublished, data will be obtained from the financial statements annual manufacturing companies listed on the Stock Exchange the period 2015 to 2017. the data source comes from the Indonesia Stock Exchange through the website iewww.idx.co.id,

The data collection system in this study is done by:

1. Methods Study Library

Is to do a literature review, exploration, and assessment of various literature such as books, journals, magazines, literature, and other sources to support research.

\section{Documentation}

Is the technique of collecting data by recording data related to the variables studied from documents related to this research.

Data analysis techniques in this study using Structural Equation Modelbased Partial Least Square (PLS-SEM) software SmartPLS 3.0. SEM-PLS analysis techniques are used as data analysis because it has its own advantages and efficiency compared to other analytical techniques technique. The SEM-PLS equation model in this study were divided into two as follows:

a. Outer Equation Model (measurement model)

-Exogenous latent variable 1

$$
\mathrm{X} 1=\lambda \times 1 \xi 1+\delta 1(1)
$$

-Exogenous latent variable 2

$$
\mathrm{X} 2=\lambda \mathrm{X} 2 \boldsymbol{\xi} 2+\delta 2(2)
$$

- Endogenous latent variable 1

$$
\text { Y1 }=\lambda \mathbf{Y} 1 \eta 1+\varepsilon 1(3)
$$

-Endogenous latent variable 2

$$
Y 2=\lambda Y 2 \eta 2+\varepsilon 2 \text { (4) }
$$

-Endogenous latent variable 3

$$
Y 3=\lambda Y 3 \eta 3+\varepsilon 3(5)
$$

a. Inner Equation Model

$$
\begin{aligned}
& \eta 1=\gamma 1 \xi 1+\gamma 2 \xi 2+\varsigma 1(6) \\
& \eta 2=\beta 1 \eta 1+\gamma 3 \xi 1+\gamma 4 \xi 2+\varsigma 1(7) \\
& \eta 3=\beta 2 \eta 1+\beta 3 \eta 2+\gamma 5 \xi 1+\gamma 6 \xi 2+\varsigma 1(8)
\end{aligned}
$$

Information:

X1: DK $\lambda$ X1: Outer Loading BOC

X2: KAגX2: Outer Loading Audit Committee

Y1: VAIC $\lambda$ Y1: Outer Loading VAIC 
Y2: CSRD $\lambda$ Y2: Outer Loading CSRD

Y3: Tobin's QגY2: Outer Loading Tobin's Q

$\xi 1$ : Council Komisaris $\delta$ : Latent Variable Noise Exogenous

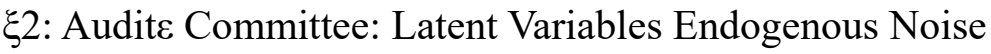

$\eta 1: \quad$ Intellectual Capital $\quad$ : Residual Value

$\eta 2: \quad$ Corporate Social Responsibility

१3: Corporate Values

$\gamma 1$ : Path coefficient Board of Commissioners on Intellectual Capital

2: Coefficient Line Audit Committee of the Intellectual Capital

\%3: Path coefficient Board of Commissioners on Corporate Social Responsibility

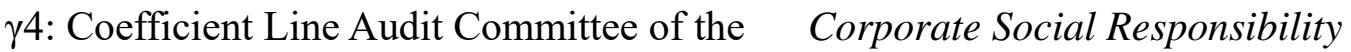

$\gamma 5$ : Path coefficient Board of Commissioners on Corporate Values

\%6: Coefficient Line Audit Committee of the Company Value

$\beta 1$ : coefficient Line

Intellectual Capital on Corporate Social Responsibility

32: Coefficient Line Intellectual Capital of the Company Value

$\beta 3$ : coefficient Line

Corporate Social Responsibility of the Company Value

\section{Results and Discussion}

Population-based companies listed on the Stock Exchange 2015-2017 period, this study used several samples of consistent manufacturing companies listed in the Stock Exchange during the three years from 2015-2017. The details of the study sample acquisition as follows:

Table 1. Criteria for Research Samples

\begin{tabular}{|c|c|c|}
\hline No & Criteria & total \\
\hline 1. & Manufacturing companies listed in Indonesia Stock Exchange in 2015-2017 & 432 \\
\hline 2. & $\begin{array}{l}\text { Manufacturing companies listed in Indonesia Stock Exchange continuously } \\
\text { during 2015-2017 }\end{array}$ & 140 \\
\hline 3. & $\begin{array}{l}\text { Manufacturing companies during the years } 2015-2017 \text { which does not issue } \\
\text { financial statements in the currency of rupiah }\end{array}$ & $(28)$ \\
\hline 4. & $\begin{array}{l}\text { Manufacturing companies during the years } 2015-2017 \text { which has no annual } \\
\text { report and the audited financial statements that have been published }\end{array}$ & $(38)$ \\
\hline 5. & Manufacturing companies that suffered losses during the years 2015-2017 & $(33)$ \\
\hline \multicolumn{2}{|r|}{ The number of companies that can be sampled } & 41 \\
\hline \multicolumn{2}{|c|}{ The amount of data ( $41 \times 3$ years) } & 123 \\
\hline
\end{tabular}

Source: Secondary data that has been processed (2019)

Based on the table, it can be seen that the number of companies that can be used as research objects and in accordance with the criteria is 41 companies. Observation period for three years, so that observations during the period 2015-2017 is 3 x 41 sample of 123 observations or data. 
Table 2. Descriptive Statistics Test Results

\begin{tabular}{|c|c|c|c|c|c|c|}
\hline & $\mathrm{N}$ & MIN & MAX & mean & median & STDEV \\
\hline board of Commissioners & \multirow{5}{*}{123} & 2 & 8 & 4,293 & 3 & 1.7 \\
\hline The Audit Committee & & 3 & 4 & 3.073 & 3 & 0.26 \\
\hline Intellectual Capital & & 5 & 111.8 & 33.174 & 26 & 24.008 \\
\hline Corporate Social Responsibility & & 0.1 & 0.6 & 0.402 & 0.4 & .109 \\
\hline The value of the company & & 0.3 & 14688.8 & 742.398 & 1.6 & 2127.02 \\
\hline
\end{tabular}

Source: Secondary Data are processed, 2019

Based on the result of a descriptive statistic in the table above, it can be shown that the commissioners variable has a value between 2 and 8 with an average value of 4,293, the median of three and a standard deviation of 1.7. This indicates that the data on the variable commissioners have a good degree of accuracy because the average value is higher than the mean and standard deviation.

Variable audit committee has a value between 3 to 4 with an average value of 3.073 , the median of three and a standard deviation of 0.26 . This indicates that the variable data on the audit committee has a good degree of accuracy because the average value is higher than the mean and standard deviation.

variables intellectual capitalhas a value of between 5 to 111.8 with an average value of 33.174, the median of 26 and a standard deviation of 24.008. This indicates that the data on the variable intellectual capital has a good degree of accuracy because the average value is higher than the standard deviation value and higher than the middle.

variables corporate social responsibilityhas a value between 0.1 to 0.6 with an average value of 0.402 , the median value of 0.4 and the value of a standard deviation of 0.109 . This indicates that the variable data on corporate social responsibility has a good degree of accuracy because the average value is higher than the standard deviation value and the value of the center.

Variable value of the company has a value between 0.3 up to 14688.80 with the average value is 742.398 , the median value of 1.6 and a standard deviation value of 2127.02 . This indicates that the data on the variable value of the company has an accuracy rate of less since the average value is higher than the median value and lower than the standard deviation value.

Table 3. R-Square (R2)

\begin{tabular}{l|l|l}
\hline & R Square & R Square Adjusted \\
\hline IC & .546 & .538 \\
\hline CSR & .808 & 0.805 \\
\hline The value of the company & .669 & 0.657 \\
\hline
\end{tabular}

Source: Secondary data that has been processed (2019)

Based on the results if the data in the table above, it was explained that the value of $\mathrm{R}-$ Square (R2) in the variable intellectual capital amounted to 0.546 or by $54.6 \%$. This means that the variable intellectual capital can be explained by the commissioners and audit committees of $54.6 \%$, while $45.4 \%$ is explained by other variables. Additionally, it can be seen also on the value of R-Square (R2) in the variable menunujukkan corporate social 
responsibility at a value of 0.808 or $80.8 \%$. This means that the variable corporate social responsibility can be explained by the commissioners and audit committees of $80.8 \%$ while the remaining $19.2 \%$ is explained by other variables. While the value of R-Square (R2) in the variable value of the company amounted to 0.669 or $66.9 \%$. This means that the variable value of the company can be explained very well by the variable board of directors, audit committee, intellectual capital.

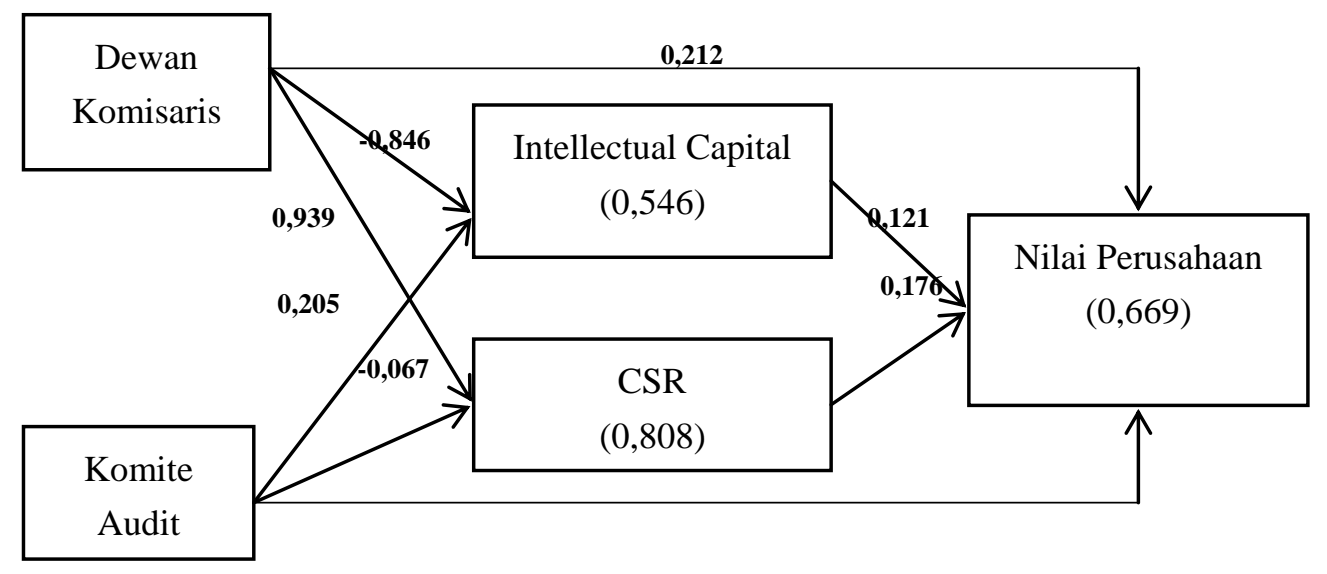

Figure 2. Model PLS Path Algorithm

Based on the results of outer loading that have been exposed to Table 3 and figure 2 it can be made equal to the outer and inner model of the model as follows:

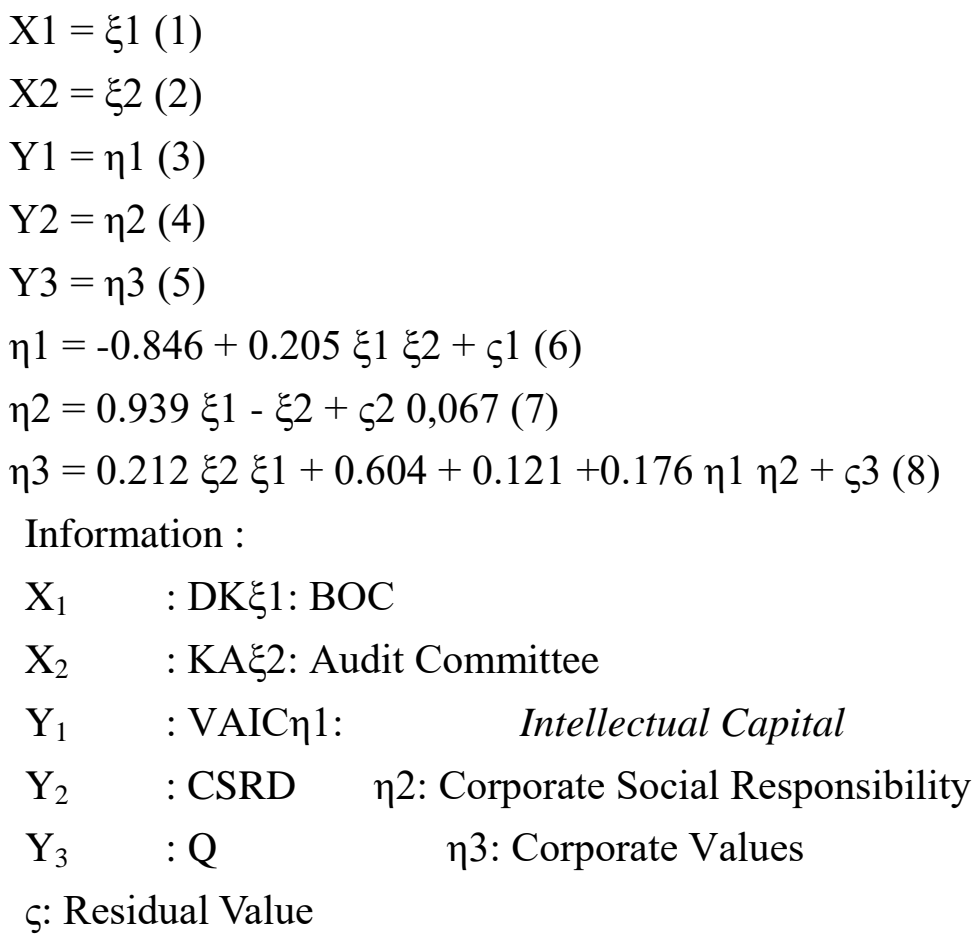

On the outer and inner equation model of the above, it can be explained that:

Each individual manifest variables or indicators menunjukkaan equivalent results with each of the latent variables are exogenous and endogennya; 
Each increase of one unit on board of commissioners $(\Xi 1)$ will lower the intellectual capital $(\eta 1)$ of 0.846 assuming other variables constant;

Each increase of one unit on board of commissioners ( $\Xi 1)$ it will raise corporate social responsibility $(\eta 2)$ of 0,939 , assuming other variables constant;

Each increase of one unit on the board of directors $(\Xi 1)$ it will raise the value of the company $(\eta 3)$ of 0.212 assuming other variables constant;

Each increase of one unit on the audit committee ( $(\xi)$ it will raise the intellectual capital ( $\eta 1)$ of 0.205 assuming other variables constant;

Each increase of one unit on the audit committee $(\Xi 2)$ will lower the corporate social responsibility $(\eta 2)$ of 0,067 , assuming other variables constant;

Each increase of one unit on the audit committee ( $(\xi 2)$ it will raise the value of the company $(\eta 3)$ of 0.604 assuming other variables constant;

Each increase of one unit on intellectual capital (H1) it will raise the value of the company $(\eta 3)$ of 0.121 assuming other variables constant;

Each increase of one unit on corporate social responsibility (H2) it will raise the value of the company $(\eta 3)$ of 0.176 assuming other variables constant.

Table 4. Path Coefficients

\begin{tabular}{l|c|c|c|c|c}
\hline & $\begin{array}{c}\text { Original } \\
\text { Sample (O) }\end{array}$ & $\begin{array}{c}\text { Sample } \\
\text { Mean (M) }\end{array}$ & $\begin{array}{c}\text { Standard } \\
\text { Deviation } \\
\text { (STDEV) }\end{array}$ & $\begin{array}{c}\mathrm{t} \\
\text { Statistic }\end{array}$ & P Value \\
\hline $\begin{array}{l}\text { BOC Intellectual } \\
\text { Capital }\end{array}$ & -0846 & -0846 & 0044 & 19155 & $\mathbf{0 0 0 0}$ \\
\hline $\begin{array}{l}\text { board of Commissioners } \\
\rightarrow \text { CSR }\end{array}$ & 0939 & 0933 & 0028 & 33576 & $\mathbf{0 0 0 0}$ \\
\hline $\begin{array}{l}\text { board of Commissioners } \\
\begin{array}{l}\text { The value of the } \\
\text { company }\end{array}\end{array}$ & 0212 & 0232 & 0074 & 2,886 & $\mathbf{0 0 0 2}$ \\
\hline $\begin{array}{l}\text { The Audit Committee } \rightarrow \\
\text { Intellectual Capital }\end{array}$ & 0205 & 0202 & 0039 & 5,201 & $\mathbf{0 0 0 0}$ \\
\hline $\begin{array}{l}\text { The Audit Committee } \rightarrow \\
\text { CSR }\end{array}$ & -0067 & -0061 & 0026 & 2,545 & $\mathbf{0 0 0 6}$ \\
\hline $\begin{array}{l}\text { The Audit Committee } \rightarrow \\
\text { The value of the company }\end{array}$ & 0604 & 0602 & 0085 & 7096 & $\mathbf{0 0 0 0}$ \\
\hline $\begin{array}{l}\text { Intellectual Capital } \rightarrow \text { The } \\
\text { value of the company }\end{array}$ & 0121 & 0138 & 0068 & 1,767 & $\mathbf{0 0 3 9}$ \\
\hline $\begin{array}{l}\text { Corporate Social } \\
\text { Responsibility } \rightarrow \text { The } \\
\text { value of the company }\end{array}$ & 0176 & 0198 & 0094 & 1,876 & $\mathbf{0 0 3 1}$ \\
\hline $\begin{array}{l}\text { board of Commissioners } \\
\begin{array}{l}\text { Intellectual Capital } \rightarrow \\
\text { The value of the company }\end{array}\end{array}$ & -0102 & -0116 & 0054 & 1,893 & 0029 \\
\hline $\begin{array}{l}\text { The Audit Committee } \rightarrow \\
\text { Intellectual Capital } \rightarrow \text { The } \\
\text { value of the company }\end{array}$ & 0025 & 0027 & 0012 & 2106 & 0018 \\
\hline $\begin{array}{l}\text { board of Commissioners } \\
\rightarrow \text { Corporate Social }\end{array}$ & 0165 & 0184 & 0086 & 1,924 & 0027 \\
\hline
\end{tabular}




\begin{tabular}{l|l|l|l|l|l}
\hline $\begin{array}{l}\text { Responsibility } \rightarrow \text { The } \\
\text { value of the company }\end{array}$ & & & & & \\
\hline $\begin{array}{l}\text { The Audit Committee } \rightarrow \\
\begin{array}{l}\text { Corporate Social } \\
\text { Responsibility } \rightarrow \text { The } \\
\text { value of the company }\end{array}\end{array}$ & -0012 & -0012 & 0008 & 1,561 & 0060 \\
\hline
\end{tabular}

Source: Secondary Data that has been processed (2019)

Table 5. Conclusion Test Results

\begin{tabular}{|c|c|c|c|c|}
\hline & Lane & hypothesis & result & Conclusion \\
\hline $\mathrm{H} 1$ & $\begin{array}{l}\text { board of } \\
\text { Commissioners } \rightarrow \\
\text { Intellectual Capital }\end{array}$ & $\begin{array}{l}\text { Significant } \\
\text { positive }\end{array}$ & $\begin{array}{l}\text { Significant } \\
\text { negative }\end{array}$ & Hypothesis 1 Rejected \\
\hline $\mathrm{H} 2$ & $\begin{array}{l}\text { board of } \\
\text { Commissioners } \rightarrow \\
\text { CSR }\end{array}$ & $\begin{array}{l}\text { Significant } \\
\text { positive }\end{array}$ & $\begin{array}{l}\text { Significant } \\
\text { positive }\end{array}$ & Hypothesis 2 Received \\
\hline H3 & $\begin{array}{l}\text { board of } \\
\text { Commissioners } \rightarrow \\
\text { The value of the } \\
\text { company }\end{array}$ & $\begin{array}{l}\text { Significant } \\
\text { positive }\end{array}$ & $\begin{array}{l}\text { Significant } \\
\text { positive }\end{array}$ & $\begin{array}{l}\text { Hypothesis } 3 \\
\text { Accepted }\end{array}$ \\
\hline $\mathrm{H} 4$ & $\begin{array}{l}\text { The Audit Committee } \\
\rightarrow \text { Intellectual Capital }\end{array}$ & $\begin{array}{l}\text { Significant } \\
\text { positive }\end{array}$ & $\begin{array}{l}\text { Significant } \\
\text { positive }\end{array}$ & $\begin{array}{l}\text { Hypothesis } 4 \\
\text { Accepted }\end{array}$ \\
\hline H5 & $\begin{array}{l}\text { The Audit Committee } \\
\rightarrow \text { CSR }\end{array}$ & $\begin{array}{l}\text { Significant } \\
\text { positive }\end{array}$ & $\begin{array}{l}\text { Significant } \\
\text { negative }\end{array}$ & Hypothesis 5 Rejected \\
\hline H6 & $\begin{array}{l}\text { The Audit Committee } \\
\rightarrow \text { The value of the } \\
\text { company }\end{array}$ & $\begin{array}{l}\text { Significant } \\
\text { positive }\end{array}$ & $\begin{array}{l}\text { Significant } \\
\text { positive }\end{array}$ & $\begin{array}{l}\text { Hypothesis } 6 \\
\text { Accepted }\end{array}$ \\
\hline H7 & $\begin{array}{l}\text { Intellectual Capital } \\
\rightarrow \text { The value of the } \\
\text { company }\end{array}$ & $\begin{array}{l}\text { Significant } \\
\text { positive }\end{array}$ & $\begin{array}{l}\text { Significant } \\
\text { positive }\end{array}$ & Hypothesis 7 Received \\
\hline H8 & $\begin{array}{l}\text { Corporate Social } \\
\text { Responsibility } \rightarrow \text { The } \\
\text { value of the company }\end{array}$ & $\begin{array}{l}\text { Significant } \\
\text { positive }\end{array}$ & $\begin{array}{l}\text { Significant } \\
\text { positive }\end{array}$ & Hypothesis 8 Received \\
\hline
\end{tabular}

Source: Secondary Data that has been processed (2019).

Based on the results of data processed in Table 4 above, it can be interpreted as follows:

Variable commissioners to intellectual capitalhas a coefficient of -0.846 parameters which can be seen in the original sample column. This indicates that the variable commissioners have a negative direction toward intellectual capital which means that if the commissioners up one unit, it can lower the value of the intellectual capital of $84.6 \%$ is assumed that other 
latent constructs anyway. On the results show the value of $p$ values of 0.000 where the results have met the requirements that $\mathrm{p}$ values $<0.05$ it can be concluded that the first hypothesis (H1) was rejected because the commissioners have a direction and a significant negative relationship to intellectual capital;

Variable commissioners to corporate social responsibility parameter has a coefficient of 0.939 . This suggests that the commissioners have a positive direction towards corporate social repsonsibility which means that, if the commissioners up one unit of the increase amounted to 93.9\% CSR assuming other constructs anyway. On the results show the value of $p$ values of 0.000 where the results have met the requirements that $\mathrm{p}$ values $<0.05$ it can be concluded that the second hypothesis $(\mathrm{H} 2)$ that commissioners received significant positive effect on corporate social responsibility;

Variable board of directors on corporate value parameter has a coefficient of 0.212 . This suggests that the commissioners have a positive direction on corporate value, which means, if the commissioners up one unit then increases the value perushaaan of $21.2 \%$ assuming the other constructs anyway. On the results show the value of $p$ values of 0.002 where the results have met the requirements that $\mathrm{p}$ values $<0.05$ it can be concluded that the third hypothesis (H3) that commissioners received significant positive effect on the value of the company;

Variables intellectual capital audit committee has a coefficient parameter of 0.205 . This indicates that the audit committee has the positive direction of the IC that is to say, if the audit committee then moved up one unit increase of $20.5 \%$ IC assuming the other constructs anyway. On the results show the value of $p$ values of 0.000 where the results have met the requirements that $p$ values $<0.05$ it can be concluded that the fourth hypothesis $(\mathrm{H} 4)$ accepted that the audit committee significant positive effect on intellectual capital;

Variable audit committee of the corporate social responsibility has a parameter coefficient of -0.067. This indicates that the audit committee has a negative direction towards corporate social responsibility, which means, if the audit committees up one unit of the lowering of corporate social responsibility by $6.7 \%$ assuming other constructs anyway. On the results of $p$ values showed a value of 0.006 in which these results have met the requirements that $p$ values $<0.05$ it can be concluded that the fifth hypothesis (H5) was rejected because of the audit committee significant effect on corporate social responsibility but with the direction of the path coefficients are negative;

Variable audit committee parameter value of the company has a coefficient of 0.604 . This indicates that the audit committee has a positive direction on corporate value, which means, if the audit committees up one unit of the increase amounted to $60.4 \%$ IC assuming the other constructs anyway. On the results show the value of $p$ values of 0.000 where the results have met the requirements that $\mathrm{p}$ values $<0.05$ it can be concluded that the sixth hypothesis (H6) accepted that the audit committee significant positive effect on the value of the company;

Variable intellectual capital on firm value parameter has a coefficient of 0.121 . This shows that intellectual capital has a positive direction on corporate value, which means, if the intellectual capital up one unit then increases the value of the company amounted to $12.1 \%$, 
assuming the other constructs anyway. On the results of $p$ values showed a value of 0.039 in which these results have met the requirements that $p$ values $<0.05$ it can be concluded that the seventh hypothesis (H7) is intellectual capital received significant positive effect on the value of the company;

Variable corporate social responsibility to corporate value parameter has a coefficient of 0.176 . This shows that corporate social responsibility has a positive direction on corporate value, which means, if the rise of the corporate social responsibility unit then increases the value of the company amounted to $17.6 \%$, assuming the other constructs anyway. On the results of $\mathrm{p}$ values showed a value of 0.031 in which these results have met the requirements that $p$ values $<0.05$ it can be concluded that the hypothesis eighth (H8) accepted that corporate social responsibility is a significant positive effect on firm value;

Variable board of directors on corporate value mediated by intellectual capitalgenerating a negative coefficient of -0.102 parameter which means that each increase of one unit of commissioners will decrease the value of the company amounted to $10.2 \%$. On the results of $\mathrm{p}$ values showed a value of 0.029 in which these results have met the requirements and it can be concluded that the board of directors remains a significant effect on the value of the company that is mediated by the intellectual capital with the direction of the path coefficients are negative;

Variable audit committee on corporate value mediated by the intellectual capital generates a positive coefficient value parameter of 0.025 means that each increase of one unit of the audit committee will be followed by the increase in the value of the company amounted to $2.5 \%$. On the results of $\mathrm{p}$ values showed a value of 0.018 in which these results have met the requirements, so that it can be concluded that the audit committee remains positive and significant impact on the value of the company that is mediated by the intellectual capital;

Variable board of directors on corporate value mediated by corporate social responsibility generate positive coefficient value parameter of 0.165 which means that each increase of one unit of commissioners will raise the value of the company amounted to $16.5 \%$. On the results of $p$ values showed a value of 0.027 in which these results have met the requirements and it can be concluded that the commissioners remained significant positive effect on firm value mediated by the intellectual capital;

Variable audit committee of the company's value-mediated corporate social responsibility generate a positive coefficient value parameter of -0.012 means that each increase of one unit of the audit committee will lower the value of the company amounted to $1.2 \%$. On the results of $\mathrm{p}$ values showed a value of 0.060 which means that the results do not meet the requirements, so that it can be concluded that the audit committee did not significantly affect the value of the company mediated dengandb corporate social responsibility towards the path coefficients are negative.

\section{References}

Bontis, N. (2002). World Congress on Intellectual Capital Readings. (Woburn: Butterworth-Heinemann.). 
Bringham, E. F., \& Houston, J. F. (2011). Dasar-dasar Manajemen Keuangan. In Edisi 11, Penerjemah Ali Akbar Yulianto. Jakarta. Salemba Empat.

Chotimah, C., \& Amanah, L. (2013). Analisis Rasio Keuanan Terhadap Return Saham dan Nilai Perusahaan. Jurnal Ilmu \& Riset Akuntansi, 2(1).

Daughter, R. Z. (2010). Influence Mechanism of GCG against CSR As Company Values with Variables Interverning on Industry Listed on the Stock Exchange the period 2006 to 2008.

Deegan, C. (2004). Financial Accounting Theory. In McGraw-Hill Book Company.

Dewi, I. R. et al. (2014). Effect of Capital Structure Of Company Value (A Study on the Mining Sector Listed on Bei Period 2009-2012. Journal of Business Administration (JAB), 17(1).

Faza, M. F., \& Hidayah, E. (2014). Intellectual Capital Influence On Profitability, Productivity, and Value The Banking Companies Listed in Indonesia Stock Exchange (BEI). Journal of Economics and Business Islam.

Fidhayatin, S., \& Goddess. (2012). Corporate Value Analysis, Corporate Performance and Growth Opportunities Against Company Stock Return on Manufacturing Companies Listing on the Stock Exchange. The Indonesian Accounting Review, 2(2), 203-214. https://doi.org/10.14414/tiar.v2i02.96

Murwaningsari, E. (2009). Relations Corporate Governance, Corporate Social Responsibilities and Corporate Financial Performance In One continum. Journal of Accounting and Finance, 11(1), 30-41.

Pramelasari, Y. (2010). the Intellectual Capital Influence on Market Value and Corporate Financial Performance.

Rara, S., \& Hadiprajitno, B. (2012). The Effect of Corporate Governance on Corporate Social Responsibility Relationships and Values Manufacturing Company listed on the Stock Exchange. Journal of Accounting and Auditing, (Diponegoro University).

Rustriani, N. (2010). Effects of Shareholding Structure On Corporate Social Responsibility Disclosure. National Simposiun Accounting X. Napier.

Sangkala. (2006). Intellectual Capital Management: New Strategies to Build Corporate Competitiveness. Jakarta: YAPENSI.

Sekaran, U. (2017). Metodologi Penelitian Untuk Bisnis. Jakarta. Salemba empat.

Suhendah, R. (2012). Intellectual Capital Influence On Profitability, Productivity, and Market Assessment on which Go Public Companies in Indonesia in the year 2005 to 2007. National Symposium on Accounting XV.

Sukmono, S., \& Yadiati, W. (2016). Effect of the board of Commissioners and the Audit Committee on theFirm Value with mediating Effect Quality Financial Reporting. Journal of Finance and Accounting. 


\section{Macrothink}

Journal of Public Administration and Governance ISSN 2161-7104 2019, Vol. 9, No. 4

Sunarsih, N. M., \& Mendra, N. P. (2012). Effect Against Intellectual Capital Value Company Financial Performance as an intervening variable in the Companies Listed on the Indonesia Stock Exchange. Journal of Accounting National Symposium XV.

Suwarjuwono, T., \& Kadir. (2003). Intellectual Capital: Treatment, Measurement and Reporting. Journal of Accounting and Finance.

Tumirin. (2007). Analysis of Good Corporate Governance and Value. Journal BETA, 6.

Ulum, I. (2008). Intellectual Capital Performance of Banking Sector in Indonesia. Journal of Accounting and Finance, 10 (University of Malang).

Ward, T. M. V. (2013). Effect of Good Corporate Governance, Corporate Social Responsibility and Financial Performance Against Corporate Values. Journal of Management Dynamics.

Windasari, O., \& Riharjo, I. B. (2017). Effects of Good Corporate Governance, Profitability and Corporate Social Responsibility Corporate Values. Journal of Studies and Research in Accounting.

Zuhroh, D., \& Sukmawati, I. P. P. H. (2003). Size Effect Analysis of Social Disclosure in the Annual Report on the Company's Investor Reaction. National Symposium Accounting VI.

\section{Copyright Disclaimer}

Copyright for this article is retained by the author(s), with first publication rights granted to the journal.

This is an open-access article distributed under the terms and conditions of the Creative Commons Attribution license (http://creativecommons.org/licenses/by/4.0/). 